\title{
The Influence of Parental Acceptance Rejection and Mother Child Attachment to Discipline among Preschool Age Children
}

\author{
Neneng Dessy Rahayu* \\ Department of Family and Consumer Sciences, \\ Faculty of Human Ecology, \\ Bogor Agricultural University \\ Dwi Hastuti \\ Department of Family and Consumer Sciences, \\ Faculty of Human Ecology, \\ Bogor Agricultural University \\ *Corresponding author: rnenengdessy@gmail.com
}

\begin{abstract}
This study aimed to analyze influence of parental acceptance rejection, mother child's attachment to discipline among preschool age children. The sample criteria of this study are mother as primary caregiver and has child who study in PAUD Mawar and Nurul Fajria, Ciasmara Village, Pamijahan district, Bogor Regency. This study involved 36 families with preschool children, which are chosen purposively. The data were analyzed using chi-square test, Pearson correlation and multiple linear regression. Parental acceptance and discipline classified to low category, the average of mother child's attachment is classified good. There was a significant positive correlation between mother child attachment with parental acceptance and discipline of children. The result of multiple linear regression showed that there is negative influence between length of mother's education to child's discipline, meanwhile there is significant positive influence between income percapita and mother child's attachment to discipline children.
\end{abstract}

Key word : Attachment, Discipline, Parental acceptance rejection, Preschool

\begin{abstract}
Abstrak
Penelitian ini bertujuan untuk menganalisis pengaruh pengasuhan penerimaanpenolakan, kelekatan ibu anak terhadap karakter disiplin anak usia prasekolah. Kriteria contoh pada penelitian ini adalah ibu sebagai pengasuh utama dan memiliki anak yang bersekolah di PAUD Mawar dan Nurul Fajriah, Desa Ciasmara, Kecamatan Pamijahan, Kabupaten Bogor. Penelitian ini melibatkan 36 keluarga dengan anak usia prasekolah yang dipilih secara purposive. Data dianalisis menggunakan uji chi-square, uji korelasi Pearson dan regresi linear berganda. Pengasuhan penerimaan dan karakter disiplin anak prasekolah termasuk dalam kategori rendah. Kelekatan yang terjalin antara ibu dan anak terkategori cukup baik. Terdapat hubungan positif signifikan antara kelekatan ibu-anak dengan pengasuhan penerimaan dan karakter disiplin. Hasil uji regresi linear berganda menunjukkan bahwa lama pendidikan ibu berpengaruh negatif terhadap karakter disiplin anak, sedangkan pendapatan perkapita dan kelekatan ibu-anak memiliki pengaruh positif terhadap karakter disiplin anak.
\end{abstract}

Kata kunci : Anak usia prasekolah, Karakter disiplin, Kelekatan ibu anak, Pengasuhan penerimaan-penolakan. 


\section{Introduction}

Early childhood is a critical period of child growth and is often referred to as the golden period. In this phase there is rapid growth and development for the next child's life. Moral development is one of the potential children that must be developed from this period. Morally mature children will be able to judge something good or bad in the face of every situation, thus avoiding immoral behavior (Puspitasari 2016). According to Lickona preschool children are in an unconditional obedient phase that is, children are easy to follow and co-operate so that they are easy to obey the command of parents or teachers (Megawangi 2009). Preschool age is the right time to form a carousel. Therefore it is very important for parents to instill discipline and values of goodness in children from an early age. Failure to plant the character early on will affect the development of subsequent child behavior.

Discipline is the ability of a person to act according to the norms or rules that apply (Sunarti 2004). Discipline levels in Indonesia are still low, especially in terms of time discipline. Some habits that indicate low levels of discipline include breakfast time, school / work time and frequent scheduling schedules that are not timely. The low level of discipline is also show that increasing behavioral problems in children such as skipping school, being punished for not doing homework, not wearing uniforms and violating traffic signs. According to Soneta (2013) undisciplined behavior associated with habitual practice. Embedding discipline early is very important to help children develop good morale at a later stage. The habits of discipline that are embedded from childhood will encourage the child to perform a behavior both automatically and consistently. Discipline behavior is one aspect that must be formed in an effort to make people with good personality (Filisyamala et al., 2016). The purpose of disciplinary behavior is to distinguish between right and wrong, good and bad and can direct the child to behave in accordance with applicable rules. Behavior of discipline is determined by external factor that is environment both family and society (Komara in Rahayu 2002).

The success of a child's growth is determined by his family (Marliani 2014). The family is the immediate environment of the child that directly affects the child's behavior. Parents play an important role in shaping the character of the child through the process of parenting that is applied. Parents with the attitude of accepting or rejecting the existence of children will affect the behavior of children in the future (Hastuti 2015). Parental acceptance reflects the attitude of parents in providing careful affection accompanied with warmth and affection can be a driver in shaping the good character of the child. The quality of parent relationships built with warmth and acceptance is an important foundation of positive child moral growth (Santrock 2007). Early childhood is in imitation, that is, it is easy to imitate everything that he sees or hears. Therefore, the duty of the parent as an agent of socialization of good values should set an example of good behavior, provide clear rules and direction about how good and bad deeds and explain the reasons for good and bad acts with the language the child understands in accordance with the stages of his age (Hastuti 2015). Positive parenting, acceptance and consistency provided by the mother will result in positive behavior of the child in accordance with environmental expectations.

Parental rejection reflects the attitude of parents who commit violence, neglect and even reject the presence of children. Many parents found that violence in the 
process of parenting such as physical punishment and verbal violence in the form of shouts, shouts and threats. Parents assume that punching, pinching, pulling ears and yelling when children do not want to learn, wake up early when going to school or behave inappropriately is the part of learning to grow children into a disciplined figure (Kurniasari 2015). Parents assume that doing so has given their child the best. But unknowingly, in fact parents have made mistakes in parenting so that children can result in the behavior of children. Care done by verbal as well as physical punishment is a form of discipline that is often misused by parents in the nurturing process, which can lead to problematic behavior in children (Gershoff 2002). Behavior problems in children such as fighting, stealing, low levels of discipline, violent crime indicate that children do not have good morals. It is risky in the progress of the nation because children as future generations of the nation's future can not fulfill its function optimally.

Quality of care provided by the mother will determine the level of emotional attachment of mother and child. Attachment is a sense of security and full of warmth given by parents and families in children (Hastuti 2015). Mother as primary caregiver closest to the child is very important to build attachment from an early age. Dewanggi (2014) states that careful attachment between mother and child will cause the child to feel safe, then the acceptance made of mother and the stimulation of a good parenting environment will have an impact on the formation of a good child character. Sensitive, responsive, consistent childcare, nursing and child-rearing patterns are a safe attachment quality (Asra and Wahyuni 2014). Children who have secure attachment, will inspire to develop positive behavior (Chang 2015). The close attachment between mother and child is a strong foundation in shaping the positive character of the child and making him a healthy person of his soul (Megawangi 2014). Early childhood period is very important to be introduced character values, that is true and false characters, good and bad characters and things that can be done and should not be done. These values are used as the basis of the child in behaving, so that children can grow and have strong character (Nurhidayah 2011).

Purpose of this study are; (1) To identify child characteristic, family characteristic, parental acceptance-rejection, mother child's attachment and character of discipline among preschool age children; (2) To analyze correlation between parental acceptance-rejection, mother child's attachment and discipline character; (3) Knowing the factors that influence the character of child discipline.

\section{Methods}

This research is part of the research Competence Grants umbrella 2017. The research design uses cross sectional study. This research was conducted in Ciasmara Village, Pamijahan Subdistrict, Bogor Regency. The research location was chosen purposively with consideration of agriculture area which still wide in Bogor Regency. The study period included data collection, processing, and report writing conducted from May to August 2017. The population of this study were families with preschoolaged children who lived in Ciasmara Village Pamijahan Sub-district in line with the umbrella research conducted. Criteria examples in this study are preschool-aged children who attend school early Mawar and Nurul Fajriah and mother as primary caregiver. The number of samples meeting the criteria was 42, but only 36 families were willing to be respondents in the study. 
The data collected in this research are primary data and secondary data. Secondary data obtained from the school includes the full name of child and parents, child's age, child's gender and parent's address. Primary data was obtained through interview process with family characteristic questionnaire tools covering mother's age, mother's education, employment status, income, and family size. Characteristics of children is measured by sex and age of child. Caring variables were measured using Parental Acceptance Rejection (PAR) instruments in Hastuti and Permatasari (2013) with Cronbach's alpha value of 0.807 . The instrument consists of 60 items of questions divided into two dimensions namely, acceptance and rejection. Dimension of acceptance consists of 20 items of affection behavior question. Rejection dimension consists of 15 questions of aggression behavior, 15 neglect behavior questions, and 10 questions of feeling unloved. The answer scale used is $0=$ never, $1=$ sometimes, $2=$ frequent and 3 = always. Stickiness was measured using the Q-Sort Attachment instrument by Water and Deane (1985) in Latifah (2016) consisting of 29 items of statements with Cronbach's alpha value of 0.701 . The answer scale used is $0=$ no and 1 $=$ yes. Meanwhile, character of the discipline was measured using a preschool character questionnaire developed by researchers from the character pillar book Megawangi et al (2010). The instrument have 12-point statement with Cronbach's alpha value of 0.706. Measurement of children's discipline character using the scale of $0-1$ answer is, $0=$ no and $1=$ yes.

The information collected is processed through the process of editing, coding, data input, cleaning, and data analysis. Data analysis uses Microsoft Office Excel and Statistical Package for Social Science (SPSS) programs. Data were analyzed descriptively (mean, standard deviation, minimum value and maximum value) and inferensia (chi square, correlation and multiple linear regression). The number of different question items in each variable dimension is composed by transforming the values / scores that have been obtained into index scores.

\section{Result}

\section{Characteristics of children and families}

Family characteristics studied include age of child, gender, mother's age, mother's education, income per capita and family size. The results showed that sample age ranged from 4 to 7 years, consisting of 14 males and 22 females. Age and parental education are factors that can determine quality of care provided to their children (Hastuti 2015). The results showed that average age of the mother (31.97 years) was in the early adult category (Hurlock 1980). The average length of maternal education is 7.64 years. That is, average mother of the sample to educate only to complete primary school. Larger income will provide adequate care and ensure the needs of the child (Elmanora 2011). Based on Bogor city poverty line of IDR 290,874 (BPS 2015), the average number of family per capita income is above the poverty line of IDR 486,849 . The number of family members in this study ranged from three to seven people with a large average family of 4 people. Based on the 2005 National Population and Family Planning Agency (NPFPA) categorization, the sample family is included in the small family category. 


\section{Parental Acceptance-Rejection}

Parental acceptance is characterized by affection nurturing, which is, lovingly. Parental rejection is characterized by aggressive parenting, neglect, and unloving feelings. The results showed that parental care showed the highest average score compared to rejection nursing. However, parental care provided by parents is still relatively low with an average value of 51.99. Likewise, when viewed from the parenting dimensions of rejection of aggressive parenting has a high enough value to be done mother to her child. This is in line with the research of Permatasari (2011) that maternal affection care is still relatively low with an average value of 34.70 and the average perigaku aggression performed by mother is also quite large at 25.50. In addition, Dewanggi (2014) states that the average mothering rejection of mothers in rural areas is still relatively high.

The results showed that more than half of the sample tended to be cared for by her mother with affection and warmth $(69,4 \%), 13,9 \%$ nurtured by aggression and neglect, while $2,8 \%$ were taken care of by unloving. This explains that in terms of parenting mother care often feel proud of every good behavior done by child $(63,9 \%)$, mother try to make child comfortable when sick $(58,3 \%)$, and mother feel that mother who need child (55.6\%). In addition, in the dimensions of acceptance also shows that mothers rarely speak to children with affection and warmth $(52.8 \%)$, praise the child when doing good $(38.9 \%)$, say the proud word $(47.2 \%)$ and mother rarely interested in something that children do $(52.8 \%)$.

Dimensions of parental rejection in terms of aggressive parenting, in this study mother more often threatened the child when not according $(52.8 \%)$, shouted to the child $(52.8 \%)$ and felt impatient / immediately scolded him when the child did wrong (38.9\%). Furthermore, in terms of parental care the biggest proportion was mother not interested to pay attention to child $(52,8 \%)$, mother did not enjoy all the time with her child $(61,1 \%)$, and mother too busy to answer child's question $(55,6 \%)$, while in terms of feelings do not love mothers more often feel annoyed when children do wrong $(47.2 \%)$.

\section{Attachment}

Attachment consists of three dimensions of explorative behavior, affectionate response and social awareness. The subscale of social awareness has the highest average (68.61) compared to the other dimensions. Attachment of child's mother as a whole can be said quite adhered to the average achievement of 66.00. Dewanggi (2014) states that villagers have a fairly good mother and child attachment level with an average score of 61.33. The results showed that almost half of the samples had moderate attachment with the mother at 41.7 percent. This explains that in the exploratory behavioral dimension child is not fussy when returning to play (63.9\%), choosing to play around the house close to his mother (69.4\%), serious and deft when playing alone (97.2\%), fearless $(69.4 \%)$ and can test toys in detail and try to use them differently $(83.3 \%)$.

In addition, in the dimension of affection response shows that as many as 80.6 percent of children share with their mothers, often embraced mother $(72.2 \%)$, not acting roughly $(75.0 \%)$, and child quickly welcomes the mother with a big smile (83.3\%). Meanwhile, the affectionate response expressed through the game shows 91.7 percent of children pretending to be parents who provide affection through their dolls or pets and 
be careful and gentle toward their toys or grooms. Furthermore, the form of child interaction with a new person shows that 77.8 percent of the children are willing to show what the child can do, want to get attention (75\%), and repeat what is approved by a new person $(80 \%)$.

\section{Character of Discipline}

According Kurniasih (2016) childhood discipline character is a behavior consistently performed by children based on established rules. The results showed that more than half of samples $(58.3 \%)$ showed a low discipline character. The character of discipline in this study consists of self-discipline, environment and ethics. The greatest proportion is in the self-discipline part of 75 percent of instances of lazy brushing of teeth especially before bedtime, irregular eating (44.4\%), not washing hands before and after meals $(36.1 \%)$. Then, environmental discipline shows that half of the samples $(52.8 \%)$ still throw garbage carelessly and love to scribble the walls (66.7\%). Furthermore, ethical discipline is characterized by pre-bedtime prayer $(55.6 \%)$ and premeal prayer $(63.9 \%)$. This shows that the character of discipline of preschool aged children in rural areas is still relatively low and has not had good character discipline with average achievement of 57,64. The results showed that preschool children have not been maximized in terms of self-discipline, environment and ethics. This is in line with research Kurniasih (2016) which shows that the character of discipline preschool children in the city of Bogor is still relatively low with an average achievement of 56.96.

\section{The Relationship between Child and Family Characteristics with Acceptance- Rejection and Attachment Care}

The Pearson correlation test results in Table 1 show that on the characteristics of per capita income families are positively correlated with affective nursing and negatively associated with neglect neglect. That is, the higher the per-capita income of the family the better the upbringing of acceptance and the lower the waiver of the parent. This is in line with Permatasari (2011) research that families with high incomes will tend to apply affective care to their children. Furthermore, the results show that large families have a significant positive relationship with parental neglect. That is, the greater the number of family members the higher the abandonment behavior performed by parents. Mukhlisoh's research (2013) explains that large families will cause families to share their time resources, so that personal interaction with children is limited.

Table 1 The correlation coefficient between the characteristics of the child and the family with acceptance-rejection and attachment care

\begin{tabular}{|c|c|c|c|c|c|}
\hline \multirow{2}{*}{ Variable } & \multicolumn{4}{|c|}{ Parental Acceptance Rejection } & \multirow{2}{*}{ Attachment } \\
\hline & $\mathrm{AF}$ & AG & NG & RJ & \\
\hline Child's age & 0.061 & -0.030 & 0.056 & -0.258 & -0.336 \\
\hline Mother's age & 0.144 & -0.325 & -0.245 & -0.131 & -0.214 \\
\hline Mother's education & 0.179 & 0.033 & -0.187 & 0.193 & 0.127 \\
\hline Family income & $0.415^{*}$ & 0.228 & $-0.343 *$ & 0.084 & 0.159 \\
\hline Family size & -0.161 & 0.119 & $0.337 *$ & 0.310 & -0.225 \\
\hline
\end{tabular}

Note: *significant in p-value $<0.05 ; * *$ significant in $\mathrm{p}$-value $<0.01$ 


\section{The Relationship between Acceptance-Rejection and Attachment Care with The Character of Discipline}

The results of the correlation test indicate that care consisting of the dimensions of affection, aggression, neglect and feelings of affection do not have a significant relationship with the character of discipline of preschoolers. Meanwhile, the attachment of the mother of the child as a whole has a significant positive relationship with the character of discipline. That is, the higher attachment that exists between mother and child, the better the character of discipline that children have (Table 2). This is in line with research studies Dewanggi (2014) and Marliani (2014) that there is a significant positive relationship between attachment to the character of children. Children who have close attachment to the mother will tend to behave positively acceptable to the environment (Ogelman and Seven 2012).

Table 2 The correlation coefficient between acceptance-rejection care and attachment to the character of the discipline

\begin{tabular}{lc}
\hline Variable & Discipline \\
\hline Parental Acceptance & \\
\hline Affection & 0.256 \\
\hline Parental Rejection & \\
\hline Aggression & -0.162 \\
Neglect & -0.219 \\
Rejection & -0.265 \\
Attachment & $0.375^{*}$ \\
\hline
\end{tabular}

Note: *significant in $\mathrm{p}$-value $<0.05 ; * *$ significant in $\mathrm{p}$-value $<0.01$

\section{Factors that Influencing Child Discipline Character}

Researchers use backward method in multiple linear regression testing, so that variables that do not have a significant influence such as family characteristics will not enter into the regression model. The use of backward method aims to get the best model and remove the variables that do not affect the character of the discipline.

The result of multiple linear regression test shows that the value of Adjusted R2 on the character of discipline is 0,231 . That is, by 23.1 percent of the variables in the model explain the influence on the character of the discipline. The rest, amounting to 76.9 percent influenced by other variables that are not examined. Table 3 shows that the duration of maternal education had a significant negative effect on the character of child discipline. That is, every increase of one year old education mother will lower the score of character discipline by 3,034 points. This is not in line with Kurniasih (2016) that the higher education is taken by the mother the better the character of discipline owned by the child. This is allegedly caused by the average value of the length of education of mothers only to complete primary school, thus indicating that with increased education does not necessarily improve the skills and insights related to mother care. The results also show that the income per capita family and viscosity have a significant positive effect on the character of child discipline. This indicates that any 100,000 increase in 
income will increase the disciplinary score by 2,779 points and each increase of one unit of attachment score will increase the discipline character score by 0.501 points. Children from high income families have better characters. This is because parents with greater incomes will provide adequate care and ensure the needs of child growth (Elmanora 2011). In addition, the close attachment process between mother and child is a strong foundation in shaping the positive character of the child (Megawangi 2014).

Table 3 Regression coefficient coefficients of factors that influence the discipline character of preschoolers

\begin{tabular}{|c|c|c|c|}
\hline \multirow[b]{2}{*}{ Variable } & \multicolumn{3}{|c|}{ Discipline Character } \\
\hline & $\begin{array}{c}\text { Unstandardized } \\
\beta\end{array}$ & $\begin{array}{c}\text { Standardized } \\
\beta \\
\end{array}$ & Sig \\
\hline Constanta & 43.595 & - & 0.048 \\
\hline Mother's education & -3.034 & -0.347 & $0.034 *$ \\
\hline Family income & 2.779 & 0.367 & $0.031 *$ \\
\hline Aggression & -0.265 & -0.161 & 0.315 \\
\hline Attachment & 0.501 & 0.325 & $0.046^{*}$ \\
\hline $\mathrm{R}^{2}$ & \multicolumn{3}{|c|}{0.319} \\
\hline Adjusted $\mathrm{R}^{2}$ & \multicolumn{3}{|c|}{0.231} \\
\hline $\mathrm{F}$ & \multicolumn{3}{|c|}{3.633} \\
\hline Sig & \multicolumn{3}{|c|}{ 0.015* } \\
\hline
\end{tabular}

Note: *significant in $\mathrm{p}$-value $<0.05 ; * *$ significant in $\mathrm{p}$-value $<0.01$

\section{Discussion}

Parenting is a time when parents provide the most basic resources to children, fulfillment, love, pay attention, and teach good values (Hastuti 2015). Parenting is the attitude of parents in interacting, guiding, and educating their children in everyday life so as to be a good person (Filisyamala et al 2016). The nurturing in this study uses Rohner's nurturing (1986) which is divided into two dimensions of acceptance and rejection. Parental care is characterized by affection and warmth. The results show that more than half of the mothers do parenting care. However, the mean maternal affection care given is still relatively low (51.99). This is because based on the results of interviews, parents assume that by giving praise or saying something fun to the child is something that can make a spoiled child so there are still a few parents who give praise to the child. In addition, when interacting with the mother's children rarely speak with warm and loving. Mom admits she feels proud when her son behaves well, but she rarely never even expresses her pride even if only by saying the word proud.

Parenting rejection in this study showed relatively high average achievement, such as aggression care $(35,49)$, neglect $(29,57)$, feeling unloved $(30,49)$. Parenting aggression can be seen from the attitude of mothers who often feel impatient / irritable when their children do wrong and threaten the child when not according to not even a few mothers who do corporal punishment such as hit and pinch. Based on the results of the interview the mother feels innocent when punching or pinching her child, because the mother assumes that with the child's physical punishment will be silent and according to. Physical punishment relates to the child's experience and subsequent behavioral development of children (Gresshoff 2002). Chang et al (2010) mentions 
mothers who use physical punishment, expressing disappointment and shouting to children tend to produce children who have aggressive behavior.

Parenting abandonment is characterized by the behavior of mothers who are not interested in caring for children, rarely spending time playing with children, considering what the child likes when making a plan and even the mother is too busy to answer the child's questions. In addition, the mother feels that can not enjoy all the time when with the child. Furthermore, upbringing is characterized by the behavior of the mother who shouts at the child when the child errs, tells her mother's embarrassment to the child and silences the child to make her feel guilty. The dimensions of parental rejection in this study indicate a higher mean value compared to maternal rejection in the Kampung Adat Urug (Permatasari 2011) and lower than Dewanggi (2014) conducted in rural areas of Urug Village.

Mothers of both schools were more likely to provide affective care, but were accompanied by relatively high parental rejection. In line with the research of Permatasari (2011) that almost all instances in urung adat urug are taken care of by her mother with affection behavior but also aggression care and also high neglect done by mother. According to Hastuti (2015) characteristics of parents will determine the quality of care in children. Revenue per capita has a significant positive relationship with parental care and negatively relates to abandonment care. In line with the research of Permatasari (2011) that families with higher incomes will apply parental care to their children. Larger income causes the family to provide adequate care and ensure the child's growing needs (Elmanora 2011). In addition, there is a significant positive relationship between the family size and the mother's neglect of care. Mukhlisoh (2013) mentions that large families will cause families to share resources to many, so the time available for personal interaction with children will be limited.

Furthermore, how a parenting or caregiver responds to the child will determine the type of emotional attachment that is formed. Without responsive and loving parenting, attachment will not be formed (Hastuti 2015). The results showed that the overall attachment of the child's mother can be labeled quite sticky. It can be seen from the average achievement and the highest proportion of each dimension of attachment. Seen from the fearless child's behavior, testing new toys in detail and using them in different ways, playing themselves seriously and deftly when playing alone. A warm and loving mother figure allows her children to feel safe in their environment, encouraging children to explore (Ratner 2014). Children who have the trust of their caregiver since childhood will be easy to adapt to their environment and able to explore the environment well. The child's affectionate response to his mother is shown in the form of often embracing the mother without being asked, sharing with the mother and not acting rudely, while with the puppet game often pretending to play as a parent who gives love to her child. Similarly, the interaction of children with strangers is shown in the form of children willing to show what the child is doing, wants to get attention and want to repeat what is approved by visiting guests.

Early childhood is a critical period of child growth, if there is an error during this process it will affect the next child's life. The critical period of the child is the right time to shape the child's character. The correlation test results show that there is a significant positive correlation between attachment and discipline characteristic. This shows that the closer the mother and the child the better the character of discipline. The results of this study in line with Dewanggi (2014) states that the attachment of the 
mother of children affect the development of children's character. The close attachment process between mother and child is a strong foundation in shaping the positive character of the child and making him a healthy person of his soul (Megawangi 2014). According to Monterio et al (2011), children who have close relationships with mothers are better able to build good relations with the surrounding environment, so children tend to behave well in accordance with the norms and rules that apply. In addition, the attachment level of the adult child's mother may prevent the child from deviant behavior (Ogelman and Seven 2012).

The character of the discipline in this study encompasses the value of selfdiscipline, environment and ethics. The results showed that the character of discipline of preschool children in rural areas Pamijahan Subdistrict, Bogor Regency is still relatively low. This explains that children in rural areas have not been maximized in terms of selfdiscipline, environment, or ethics. Seen from the behavior of children who are lazy to save in school, do not throw garbage in place, do not brush your teeth before bed, do not pray before bed, and love to doodle on the wall. Other research results (Dewanggi 2014) mentioned that the character of children in rural areas has a low average value, while research Kurniasih (2016) states that the character of discipline of childhood children in the city of Bogor is low and medium. This shows that the character of child discipline in both urban and rural areas is still relatively low. Embedding discipline early is very important to help children develop good morale at a later stage. The habits of discipline that are embedded from childhood will encourage the child to perform a behavior both automatically and consistently.

The result of regression test showed that the duration of maternal education significantly negatively influenced the character of children's discipline. This is not in line with research Kurniasih (2016) which states that the duration of maternal education has a significant positive influence with the character of the age discipline of kindergarten. Mothers who have higher education will have an understanding of the importance of the role of parents to children. With good education, parents can receive information from outside, especially on how to care for good children. However, in this study, with increased maternal education does not necessarily improve the ability and knowledge of care. Based on the results of the study showed that more than half of mothers only take education to elementary school. Lack of discipline in children is caused by an environment that does not teach discipline to children in everyday life (Khotimah and Pramesti 2016). Results in the field showed that children received more stimulation in early childhood groups than at home. Some of the causes of children misbehaving and often undisciplined are the daily parental behaviors as role models that children see (Surbakti 2012). According to Albert Bandura's theory the child will observe and imitate the behavior of his parents. Therefore, it is very important for parents to be good role models in behaving and discipline. In addition, parents need to provide habituation of discipline since childhood, so that when growing up children are accustomed and easy to adapt to the environment.

This study found a significant positive influence between family income and child discipline character. Larger income will provide adequate care and ensure the needs of children such as providing learning media and educational games that can support child development (Elmanora 2011). This shows that children from high income families will have good character discipline. In addition, mother-child attachment has a significant positive effect on the character of child discipline. In line 
with research Dewanggi (2014) which states the level of attachment of mother and child have an influence on the character of the child. Children who do not have secure attachment to the mother, they tend to behave in a deviant manner (Ogelman and Seven 2012). The results showed that the mother has less attachment with her child, thus influencing also in the process of character building of child discipline. Children have a low discipline character that includes self-discipline, environment and ethics. It is shown in terms such as lazy saving in school, eating irregularly, littering, and not brushing your teeth before bed. This suggests that it is important to build attachment between mother and child in preschool age, as the initial foundation of mother-child interaction during the next parenting process and for better child development.

Limitations in this study are the number of examples involving only 36 people with a higher proportion of women, thus resulting in no data diversity and the results can not describe the condition of preschool children as a whole in rural areas in Pamijahan Subdistrict. This study only involves the child and the mother as the respondent, so it can not see the influence of social environment characteristics around the child that may have a big influence and role on the character formation of the child.

\section{Conclusion and Suggestion}

\section{Conclusion}

The families in this study came from non-poor families with an average per capita income above the poverty line. The length of education pursued by mothers on average is only up to elementary school graduates. More than half of mothers apply afkesi nursing, but it can be said that mother's affection care is still low. On the contrary, the mother's rejection of rejection (aggression, neglect, and feeling of unloviness) showed a relatively high average performance. Maternal and child attachment level belongs to medium category or can be labeled to have close enough attachment relationship. Maternal attachment level of this child shows the highest average in the dimension of soda awareness. Children who are closely attached to the mother, will be able to interact with the social environment. Furthermore, the character of discipline of preschool aged children is low. More than half of preschoolers do not yet have a good discipline character in terms of self-discipline, environment and ethics. There is a significant relationship and influence between attachment and discipline character. The stronger the attachment that exists between mother and child, the better the character of discipline the child has. In addition, it was found that family characteristics such as per capita income and maternal education have a significant influence on the character of the discipline. The results showed that the duration of maternal education had a negative influence on the character of the discipline. Meanwhile, the higher the family income the better the character of discipline the child has. Parents who have high incomes will guarantee every child's growth needs.

\section{Suggestion}

Based on the results of research, it is very important for mothers in rural areas to get education related to positive parenting. It can be integrated through the program of Bina Keluarga Balita (BKB) and Posyandu. As an increased form of parenting 
affection, the mother should increase the frequency of giving verbal and non verbal praise to the child's good behavior. In addition, it is also important for mothers to reduce the level of violence in their care such as screaming, threatening and pinching children. It is important to do counseling about the importance of shaping the character of children from an early age, this can be realized in parenting programs that can be held by the school. It is important for the school and family to create a conducive environment so that the formation of children's character becomes more optimal. Cooperation between school and parents is also needed to monitor child development. The character of discipline can not simply appear in the child, therefore parents, especially mothers as primary caregivers, must provide good examples in behaving and providing habituation of discipline since childhood. For further research, it is advisable to examine the attachment and parental acceptance of rejection by the father.

\section{Reference}

Akhyar, Z., Maryana, Wahyu. (2015). Menanamkan nilai disiplin anak pada lingkungan keluarga di desa sungai pinang lama kecamatan sungai tabuk kabupaten banjar. Jurnal Pendidikan Kewarganegaraan. 5(10): 853-858.

Anapratiwi, D., Handayani, D., Kurniawati, Y., Sulastri, S. (2013). Hubungan antara kelekatan anak pada ibu dengan kemampuan sosialisasi anak usia 4-5 tahun (Studi pada RA Sinar Pelangi dan RA Al Iman Kecamatan Gunungpati, Semarang). Indonesian Journal of Early Childhood Education Studies. 2 (2)

Asra, Y.K., Wahyuni, S. (2014). Kecenderungan anak menjadi pelaku dan korban bulliying ditinjau dari kualitas kelekatan dengan ibu yang bekerja. Marwah. 13(1): 1-20 .

Chang, J.H., Yeh, T.L. (2015). The influence of parent-child toys and time of playing together on attachment. Procedia Manufacturing. $3: 4921-4926$.

Dewanggi, M. (2014. Pengaruh kelekatan, gaya pengasuhan, dan kualitas lingkungan pengasuhan terhadap karakter anak perdesaan dan perkotaan. [Tesis]. Bogor (ID): Institut Pertanian Bogor.

Elmanora, Muflikhati, I., Alfiasari. (2012). Gaya pengasuhan, dan perkembangan sosial emosi anak usia sekolah pada keluarga petani kayu manis. Jurnal Ilmu Keluarga dan Konsumen. 5(2):128-137.

Filisyamala, J., Hariyono, Ramli, M. (2016). Bentuk pola asuh demokratis dalam kedisiplinan siswa SD. Jurnal Pendidikan. 1(4): 668-672.

Gershoff, T.E. (2002). Corporal Punishment by Parents and Associated Child Behaviors and experiences: a meta-analytic and theoretical review. Psychological Bulletin. 128 (4): 539-579.

Halpenny, A.M., Nixon, E., Watson, D. (2009). Parenting styles and discipline: parents' perspectives. Dublin: Departement of Health and Children.

Hastuti, D., Permatasari, C.L. (2013). Nilai budaya, pengasuhan penerimaan-penolakan, dan perkembangan sosial anak usia 3-5 tahun pada keluarga kampung adat urug,Bogor. Jurnal ilmu keluarga dan konsumen. 6 (2): 91-99.

. (2015. Pengasuhan: teori, prinsip dan aplikasinya di Indonesia. Bogor (ID): IPB Press. 
Hernawati, N., Hildayani, R., Lestari, P. (2012). Peran kualitas kelekatan ibu-anak, gender anak dan rasio guru-anak terhadap kualitas hubungan guru-anak usia prasekolah. Jurnal ilmu keluarga dan konsumen. 5 (2): 120-127.

Khotimah, N. Pramesti, E.D. (2016). Pengaruh pola asuh otoriter terhadap kedisiplinan anak usia 4-6 tahun. Jurnal PAUD Teratai. 5(3): 187-190.

Kurniasari, A. (2015). Kekerasan versus disiplin dalam pengasuhan anak violence versus discipline in parenting. Sosio Informa. 1(2): 141-159.

Latifah, E.W. (2016). Pengaruh pengasuhan ibu dan nenek terhadap perkembangan kemandirian dan kognitif anak usia prasekolah. [tesis]. Bogor (ID): Institut Pertanian Bogor.

Marliani, Y.F. (2014). Pengaruh metode sosialisasi dan kelekatan ibu terhadap karakter remaja di Kelurahan Situ Gede Kota Bogor. [skripsi]. Bogor (ID): Institut Pertanian Bogor.

Megawangi, R. (2009). Solusi yang Tepat untuk Membangun Bangsa: Pendidikan Karakter. Bogor (ID): Indonesia Heritage Foundation.

(2014). Kelekatan Ibu-Aanak Kunci Membangun Bangsa. Bogor (ID): Indonesia Heritage Foundation.

Mukhlisoh, F. (2013). Pengaruh modal sosial dalam keluargadan pengasuhan penerimaan-penolakanterhadap katakter kesdaran dan kontrol diri anak. [Skripsi]. Bogor (ID): Institut Pertanian Bogor.

Nurhayati, H. (2015). Hubungan kelekatan aman (secure attachment) anak pada oangtua dengan kemandirian anak kelompok B TK PKK 37 Dodogan JatiMulyo Dlingo Bantul. Jurnal Pendidikan Guru Pendidikan Anak Usia Dini. Ed. Ke- 9.

Nurhidayah, S. (2011). Kelekatan (attachment) dan pembentukan karakter. Turats. 7(2): 78-83.

Ogelman, H.G., Seven, S. (2012). Investigating preschool children's attachment styles and peer relationships. Procedia Social and Behavioral Sciences. $47: 765-770$.

Puspitasari, R. (2016). Pengaruh pola asuh disiplin dan spiritual, serta kecerdasan spiritual ibu terhadap karakter anak usia sekolah dasar di perdesaan. [Tesis]. Bogor (ID): Institut Pertanian Bogor.

Rahayu, D. (2002). Hubungan antara gaya pengasuhan disiplin orang tua dengan karakter bertanggung jawab Sekolah Dasar. [Skripsi]. Bogor (ID): Institut Pertanian Bogor.

Ratner, K. (2014). The role of parenting and attachment in identity style development. The University of Central Florida Undergraduate Research Journal. 7(1): 1526.

Sander, M.R. (2008). Triple p-positive parenting program as a public health approach to strengthening parenting. Journal of Family Psychology. 22(3):506-517.

Santrock, J.W. (2007). Perkembangan Anak. Ed. Ke-11. Jakarta (ID): Erlangga.

Soneta, S. (2013). Hubungan antara pola asuh orang tua dengan disiplin siswa di sekolah. Jurnal Ilmiah Konseling. 2(1) :174-181.

Sukardi, A.N. (2011). Kajian riwayat perkembangan anak, sensitivitas dan kelekatan ibu terhadap anak usia 3-5 tahun di Kampung Adat Urug, Kabupaten Bogor. [Skripsi]. Bogor (ID): Institut Pertanian Bogor.

Sunarti, E. (2004). Mengasuh Dengan Hati: Tantangan yang Menyenangkan. Jakarta (ID): PT Elex Media Komputindo. 